CLINICAL HEMORHEOLOGY, Vo1. 1, pp. 443-444, 1981 0271-5198/81/050443-02\$02.00/0 Printed in the USA.

Copyright (c) 1982 Pergamon Press Ltd. All rights reserved.

\title{
ACCOUNT OF INTRODUCTORY SPEECH PRIOR TO GEORGE W. SCOTT BLAIR'S LECTURE ON THE HISTORY OF RHEOLOGY
}

\author{
Alfred L. Copley \\ Laboratory of Biorheology \\ Polytechnic Institute of New York, Brooklyn, NY 11201, USA
}

Our Readers will be interested in George W. Scott Blair's brief 'History of Rheology', included in this double issue and his role in the organization of this new science.

During his introductory remarks as Chairman of the Session of this invited Conference Lecture, Sir John Stallworthy, President of the Royal Society of Medicine, asked if I was in the audience. When I stood up, he called upon me, without prior notice, to introduce George Scott Blair. I gladly obliged and in my speech told the audience the story of my close association with my friend George.

Although I first met George W. Scott Blair in 1948 during the First International Congress on Rheology, our association began in 1957, after I moved from Paris to London, where I acted as Head of the Medical Research Laboratories of Charing Cross Hospital Medical School (University of London). There I held the position as Director of Research on Vascular Diseases for nearly three years before returning to New York City in the end of December 1959. George Scott Blair, who, for many years, was Head of the Physics Department at the National Institute for Research in Dairying-NIRD(University of Reading) at Shinfield, was well known for his rheological studies on cow milk products, his biorheological research on cervical mucus in cows and also for his research, in association with gynecologists, on cervical mucus in women. During my stay in London, I introduced George to hemorheology for which he had a keen interest. This led to many fruitful combined hemorheological research studies. It also brought about the first conference entirely devoted to hemorheology, entitled "The Flow of Blood in Relation to the Vessel Wall", held in London at Charing Cross Hospital Medical School in 1958 (1).

Our close cooperation contributed in many ways to the advancement of biorheology as an organized science, initiated at the above International Congress on Rheology nine years earlier in Holland. It also contributed to the organization of hemorheology as a vigorous branch of the new science of biorheology $(2-9)$. 
The founding of the journal BIORHEOLOGY in London in November $1959(3,7,8)$ and its first publication by Pergamon Press Ltd., Oxford in July 1962 continued our close association as co-Editorsin-Chief until his retirement from the journal in 1978 due to his failing eyesight.

I enjoyed my many visits with George and his wife Rita in Shinfield, in London and, after George's retirement from the NIRD, in Iffley, Oxford.

\section{REFERENCES}

1. SCOTT BLAIR, G.W. The flow of blood in relation to the vessel wal1. Nature (London), 182, 90-91, 1958.

2. COPLEY, A.L. Presidential address honoring George W. Scott Blair. Ceremony of Poiseuille award. In: Theoretical and Clinical Hemorheology. Proc. 2. Internat. Conf. Internat. Soc. of Hemorheology, University of Heidelberg, F.R.G., 27.7. to 1.8.1969. H.H. Hartert and A.L. Copley (Eds.). Berlin Heidelberg - New York: Springer-Verlag, 1971, pp. 5-9.

3. COPLEY, A.L. Biorheology as an organized science. Biorheology, 10, 83-86,“1973; heologica Acta, 12, 89-91, 1973.

4. SCOTT BLAIR, G.W. Poiseuille award ceremony for A.L. Copley. Presentation address. Biorheology, 10, 263-264, 1973.

5. COPLEY, A.L. George W. Scott Blair: The scientist and the man. J. Texture Studies (D. Reidel Publ. Co., Dordrecht, Ho1land $), \underline{4}, 10-12,1973$.

6. COPLEY, A.L. Foreword. In: G.W. Scott Blair and D.C. Spanner. An Introduction to Biorheology. Amsterdam - Oxford - New York: Elsevier Scientific Publ. Co., 1974, 228 pp., pages V-VII.

7. COPLEY, A.L. A tribute to George William Scott Blair, Biorheology, 15, 357-360, 1978 .

8. COPLEY, A.L. Convocation address: Prospects of biorheology in the future. Biorheology, 15, 375-386, 1978.

9. COPLEY, A.L. and SEAMAN, G.V.F. The meaning of the terms rheology, biorheology and hemorheology. Clinical Hemorheology, 1 , $117-119,1981$. 